\title{
Erratum to: Chronic alcohol consumption enhances myeloid-derived suppressor cells in B16BL6 melanoma-bearing mice
}

\author{
Hui Zhang • Gary G. Meadows
}

Published online: 24 April 2010

(C) Springer-Verlag 2010

\section{Erratum to: Cancer Immunol Immunother DOI 10.1007/s00262-010-0837-x}

Unfortunately, Figs. 1 and 4 have some errors in the original publication. The symbols in Fig. 1c should read:
Circle water-drinking mice. Square alcohol-consuming mice. For Fig. 4 the dot blot for Fig. 4a should be transposed with the dot blot in Fig. 4b.

The correct versions of figures are given below.
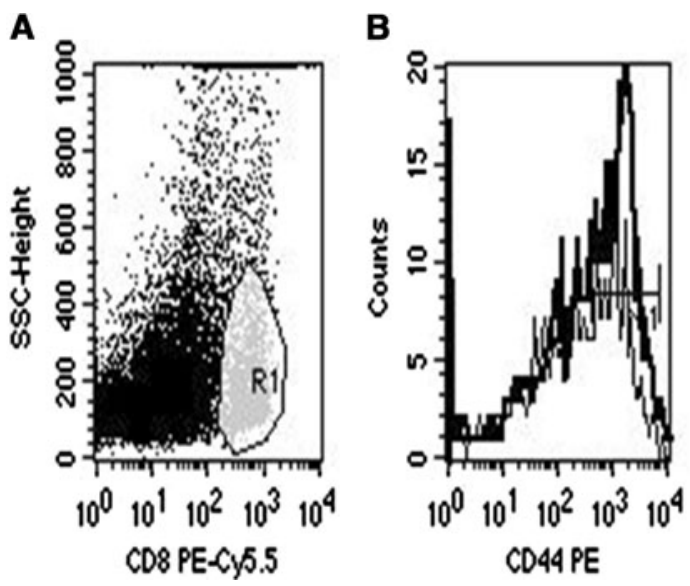

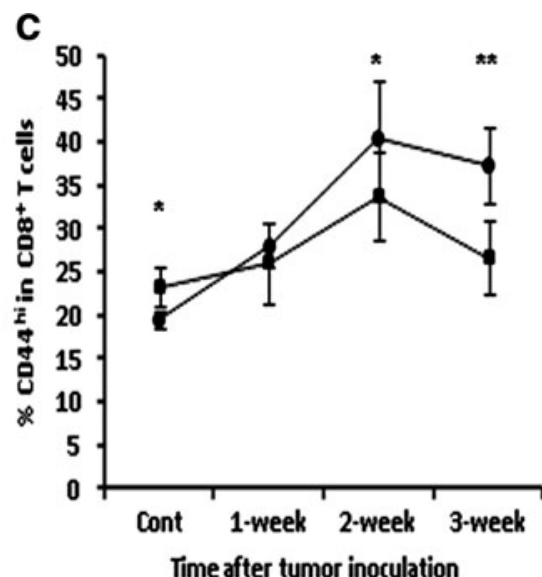

Fig. 1 Effects of chronic alcohol consumption on $\mathrm{CD} 44^{\text {hi }} \mathrm{CD} 8^{+} \mathrm{T}$ cells. a Dot plot showing the gated $\mathrm{CD}^{+} \mathrm{T}$ cells in splenocytes. b Histogram showing the CD $44^{\text {hi }}$ cells in the gated splenic $\mathrm{CD}^{+} \mathrm{T}$ cells of melanoma-bearing mice. c Percentage of $\mathrm{CD} 8^{+} \mathrm{CD} 44^{\mathrm{hi}}$ cells in $\mathrm{CD}^{+}$splenocytes from non-tumor injected mice (Cont) and melanoma-bearing mice at the indicated time points after tumor inoculation. Circle water-drinking mice. Square alcohol-consuming mice. Alcohol group different from water group, $* P<0.05$, $* * P<$ 0.001. Each group contained ten mice and the results are representative to two separate experiments

The online version of the original article can be found under doi:10.1007/s00262-010-0837-x.

H. Zhang · G. G. Meadows ( $₫)$

Chronic Illness Research Center,

Department of Pharmaceutical Sciences, College of Pharmacy,

Washington State University, Box 646534,

Pullman, WA 99164-6534, USA

e-mail: meadows@wsu.edu 

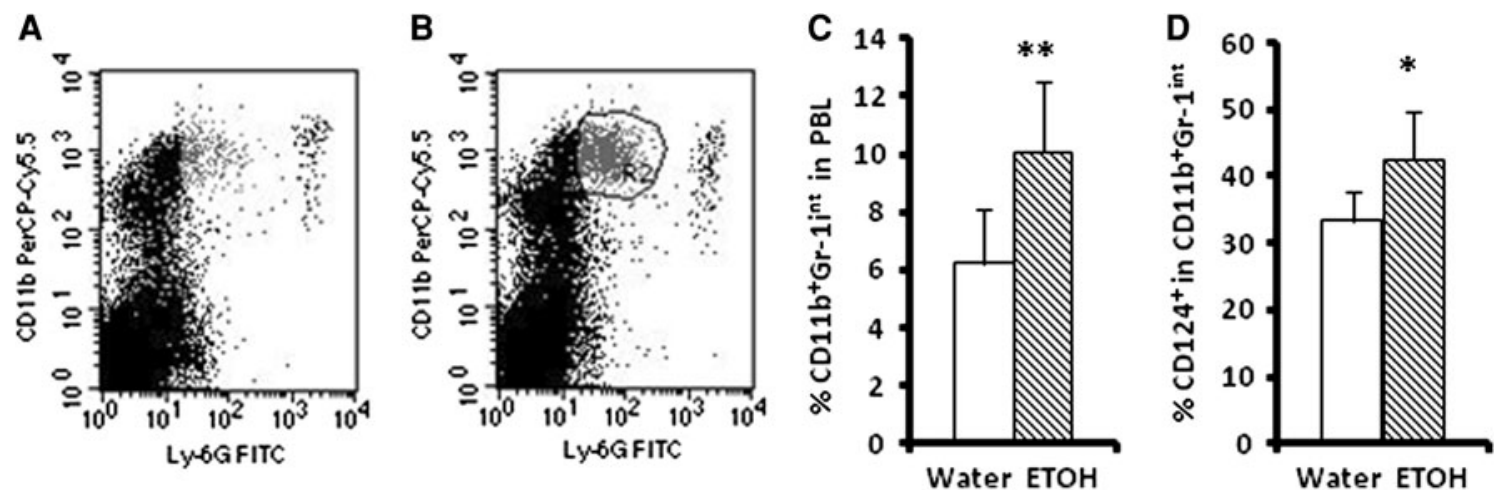

Fig. 4 Chronic alcohol consumption increases the percentages of MDSC in the PBL and of CD $124^{+}$cells in MDSC and CD11 ${ }^{+}$cells. MDSC were determined 1 week after tumor inoculation. a Dot plot of $\mathrm{CD} 11 \mathrm{~b}^{+} \mathrm{GR}-1^{\mathrm{int}}$ MDSC in the PBL of water-drinking mice. $\mathbf{b}$ Dot plot of $\mathrm{CD} 11 \mathrm{~b}^{+} \mathrm{Gr}-1^{\mathrm{int}}$ MDSC in the PBL of alcohol-consuming mice, respectivley. c Percentage of $\mathrm{CD} 11 \mathrm{~b}^{+} \mathrm{Gr}-1^{\text {int }} \mathrm{MDSC}$ in the PBL.

d Percentage of $\mathrm{CD} 124^{+}$cells in $\mathrm{CD} 11 \mathrm{~b}^{+} \mathrm{Gr}-1^{\text {int }}$ MDSC cells. ETOH group significantly different from water group, ${ }^{*} P<0.05$, $* * P<$ 0.001. ETOH Alcohol-consuming group, Water water-drinking group. Each group contained ten mice and the results are representative to two separate experiments 